\title{
PSYCHOLOGICAL CAPITAL TRAINNING TO INCREASE WORK ENGAGEMENT
}

\author{
Moch. Akhimullah Agung Santoso \\ Email: muhammadakhimullahagung@gmail.com \\ Universitas Surabaya
}

\begin{abstract}
Abstrak
Suatu manajemen dalam perusahan mengatakan bahwa work engagement itu penting untuk diteliti, dari hasil penelitian menunjukkan bahwa karyawan yang engaged menunjukkan performansi kerja yang lebih baik. Tingginya work engagement sangat penting dalam meningkatkan performa dan produktivitas organisasi. Salah satu factor yang dapat meningkatkan work engagement dapat melalui personal resource. Dalam hal ini sebagai prediktor personal resources yaitu modal psikologis. Sehingga, dalam penelitian ini peneliti ingin melakukan pelatihan psychological capital untuk meningkatkan work engagement. Work engagement dapat dilihat dari tiga komponen utama, yaitu semangat, dedikasi dan juga penghayatan. Penelitian ini menggunakan metode eksperimen one group pretest posttest design. Instrument penelitian ini menggunakan kuesioner The Utrecht Work Engagement yang dikembangkan oleh Bakker et al. (2003). Berdasarkan hasil penelitian ini ditemukan bahwa terdapat perubahan tingkat work engagement pada partisipan sebelum diadakannya pelatihan dan sesudah diadakannya pelatihan, dengan nilai signifikansi $0.002(\mathrm{p}<0.05)$.
\end{abstract}

Kata kunci: Psychological Capital; Work Engagement; Training

\begin{abstract}
Abstrac
A management in the company said that work engagement is important to study, the results of the study showed that engaged employees showed better work performance. The high level of work engagement is very important in improving organizational performance and productivity. One factor that can increase work engagement can be through personal resources. In this case as a predictor of personal resources, namely psychological capital. So, in this study the researchers wanted to conduct psychological capital training to improve work engagement. Work engagement can be seen from three main components, namely passion, dedication and appreciation. This study uses a one group pretest posttest design experimental method. The research instrument used the Utrecht Work Engagement questionnaire developed by Bakker et al. (2003). Based on the results of this study it was found that there were changes in the level of work engagement among participants before the training and after the training, with a significance value of $0.002(p<0.05)$.
\end{abstract}

Key word: Psychological Capital; Work Engagement; Training

PENDAHULUAN

Suatu manajemen dalam perusahan mengatakan bahwa work engagement itu penting untuk diteliti, dari hasil penelitian menunjukkan bahwa karyawan yang engaged menunjukkan performansi kerja yang lebih baik (Demerouti \& Cropanzano 2010; Christian, Garza \& Slaughter 2011). Tingginya work engagement sangat penting dalam meningkatkan performa dan produktivitas organisasi.
Menurut Marciano (2010) seseorang pekerja yang engaged akan berkomitmen terhadap tujuan, menggunakan segenap kemampuannya untuk menyelesaikan tugas, menjaga perilakunya saat bekerja, memastikan bahwa dia telah menyelesaikan tugas dengan baik sesuai dengan tujuan dan bersedia mengambil langkah perbaikan atau evaluasi jika memang diperlukan. Work engagement memiliki beberapa keuntungan yaitu meningkatkan produktivitas, 
meningkatkan keuntungan, menambah efisiensi meurunkan turnover, mengurangi ketidakhadiran, mengurangi penipuan, meningkatkan kepuasan konsumen, mengurangi kecelakaan kerja dan meminimalkan keluhan karyawan.

Work engagement merupakan suatu kondisi dimana individu memiliki pikiran yang positif serta memiliki motivasi yang tinggi dalam kaitannya dengan pekerjaannya (Schaufeli dan Bakker, 2004). Bakker dan Sanz-Vergel (2013) menyatakan bahwa karyawan dapat memelihara kesejahteraan psikologis dan mengatasi tuntutan pekerjaan yang dihadapi dikarenakan adanya interaksi antara tuntutan pekerjaan dan sumber daya pribadi. Kedua hal tersebutlah yang menjadi kunci dari work engagement. Karyawan yang engaged akan lebih baik memanfaatkan peluang promosi yang akan meningkatkan kapasitas mereka dalam regulasi emosi (Hobfoll dalam deLange, dkk., 2008).

Berdasarkan beberapa pemaparan di atas, peneliti mengacu pada definisi work engagement Schaufeli dan Bakker (2004) sebagai work engagement merupakan suatu kondisi dimana individu memiliki pikiran yang positif serta memiliki motivasi yang tinggi dalam kaitannya dengan pekerjaannya. Kondisi tersebut juga ditandai dengan semangat yang tinggi (vigor), dedikasi (dedication), dan kedalaman fokus (absorption).

Bukti mengenai anteseden dan konsekuensi dari keterikatan kerja dapat diatur dalam keseluruhan model keterikatan kerja. Dalam membangun model ini, kita menggunakan dua asumsi dari model permintaan pekerjaan (JD-R) (Bakker dan Demerouti, 2007; Demerouti et al., 2001). Selanjutnya, kami menggunakan karya Xanthopoulou (2007), yang mengembangkan model JD$\mathrm{R}$ dengan menunjukkan bahwa pekerjaan dan personal resources saling terkait, dan person resources dapat menjadi prediktor independen untuk keterikatan kerja. Dengan demikian, karyawan yang memiliki nilai tinggi pada optimisme, selfefficacy, ketahanan dan harga diri mampu memobilisasi job resources mereka, dan umumnya lebih terlibat dalam pekerjaan mereka. Dalam hal ini sebagai prediktor personal resources yaitu modal psikologis Hal ini didukung oleh penelitian yang dilakukan oleh Rostianda dan Lihardja (2013) yang menyatakan bahwa adanya hubungan positif antara modal psikologis dengan keterikatan kerja. Disisi lain Prihatsanti dkk (2013) menunjukkan adanya indikasi hubungan positif antara modal psikologis dan keterikatan kerja, dimana modal psikologis menyumbang sebanyak 51,3\% dari keterikatan kerja. 
Modal psikologis adalah kondisi psikologi positif individu yang ditandai dengan keyakinan diri atau kepercayaan diri, optimisme, harapan (hope), dan ketahanan (Luthans, Youssef, dan Avolio, 2007). Jika individu memiliki modal psikologis yang tinggi ia dapat melakukan pekerjaannya dengan lebih baik. Individu dengan modal psikologis yang tinggi akan lebih terikat dengan pekerjaannya karena individu tersebut akan lebih yakin dan optimis dengan kemampuannya dalam menyelesaikan pekerjaannya. Menurut penelitian oleh Rostianda dan Lihardja (2013) yang menyatakan bahwa adanya hubungan positif antara modal psikologis dengan keterikatan kerja, hal ini tentu saja didukung dengan nilai pengaruh yang mencapai $37,9 \%$.

Bakker, Albrecht, dan Leiter (2011), menjelaskan bahwa terdapat berbagai program dalam meningkatkan tingkat work engagement, yaitu pembenahan sistem perusahaan (organizational development strategies) melalui kebijakan-kebijakan yang diterapkan oleh pihak manajemen agar terintegrasi dengan engagement pegawai dan program intervensi yang secara langsung ditujukan pada level pegawai, seperti training dan coaching. Lebih lanjut, Bakker, Albrecht, dan Leiter (2011) juga menjelaskan program peningkatan work engagement dapat berfokus melalui pengembangan personal resource seperti psychological capital (hope, optimism, resilience, dan efficacy) pada pegawai. Oleh karena itu, pelatihan psychological capital merupakan intervensi yang tepat dalam mengatasi berbagai gap yang terjadi pada perusahaan ini.

\section{METODE PENELITIAN}

Metode penelitian ini menggunakan metode eksterimen, dengan menggunakan one group posttest pretest design. Pada penelitian ini, dilakukan pada subjek yang sama, dimana sebelum diadakannya pelatihan, peneliti mengukur tingkan work engagement pada peserta, dan setelah dilakukannya pelatihan, peneliti mengukur kembali tingkat work engagement subjek.

\section{Partisipan}

Partisipan dari penelitian ini melibatkan 16 peserta. Seluruh peserta merupakan karyawan aktif PT. Bhanda Ghara Reksa (Persero) yang telah bekerja lebih dari 1tahun. Peserta diikuti oleh beberapa divisi, yaitu keuangan, sekertaris, pemasaran, operasional dan SDM.

Skala

Penelitian ini dilakukan untuk meningkatkan work engagement, sehingga skala yang digunakan adalah Uterech Work Engagement Scale yang dikembangkan oleh Bakker et al. (2003) 
yang memiliki 17 aitem. Kuesioner ini diberikan kepada partisipan sebelum dilakukannya pelatihan dan sesudah pelatihan. Hal ini ditujukan untuk melihat apakah ada perubahan tingkat work engagement setelah dilakukannya pelatihan.

\section{HASIL PENELITIAN}

\section{Uji Normalitas}

Uji normalitas menggunakan analisis Kolmogorov Smirnov (K-S), dengan menggunakan IBM SPSS 23. Uji ini digunakan untuk melihat apakah sebaran data kepada partisipan bersifat normal. Pengujian ini hanya dilakukan pada data posttest. Data dapat dikatakan normal bila nilai signifikansinya lebih dari 0.05 .

Tabel 1. Uji Normalitas

\begin{tabular}{lcc}
\hline $\begin{array}{l}\text { Work } \\
\text { Engagement }\end{array}$ & Significance & Information \\
\hline & 0,07 & Normal
\end{tabular}

Berdasarkan hasil uji normalitas Kolmogorov Smirnov (K-S) ditemukan bahwa hasil normalitasnya sebesar 0.07 (>0.05). hasil tersebut menunjukan bahwa data terdistribusi normal dan dapat dilanjutkan menggunakna uji parametric.

\section{Uji Homogenitas}

Uji homogenitas pada penelitian ini di lakukan menggunakan IBM SPSS 20. Pengujian ini digunakna untuk melihat apakah varian dari partisipan homogen.
Data dapat dikatakan homogeny bila nilai signifikansinya lebih dari 0.05 .

Tabel 2. Uji Homogenitas

\begin{tabular}{ccc}
\hline $\begin{array}{c}\text { Work } \\
\text { Engagement }\end{array}$ & Significance & Information \\
\hline & 0,195 & Homogen \\
\hline Uji Hipotesis & & \\
\hline
\end{tabular}

Penelitian ini diuji menggunakan paired sample t-test. Berdasarkan hasil pengujian hipotesis menunjukan signifikansi sebesar $0.002(<0.05)$. Hal ini menunjukan bahwa hipotesis penelitian ini dapat diterima. Selain itu, hasil dari uji hipotesis ini menunjukan adanya peningkatan work engagement yang dilihat dari mean penelitian, dari 67.75 menjadi 71.94 .

Berdasarkan pemaparan hasil diatas dapat disimpulkan bahwa ada perbedaan yang signifikan antara work engagement sebelum diadakannya pelatihan dan setelah diadakannya pelatihan. Hal ini menunjukan bahwa pelatihan yang diberikan kepada peserta dapat meningkatkan work engagement secara signifikan.

\section{PEMBAHASAN}

Suatu manajemen dalam perusahan mengatakan bahwa work engagement itu penting untuk diteliti, dari hasil penelitian menunjukkan bahwa karyawan yang engaged menunjukkan performansi kerja yang lebih baik (Demerouti \& 
Cropanzano 2010; Christian, Garza \& Slaughter 2011). Selain itu Penelitian yang dilakukan oleh Harter, Schmidt, dan Hayes (2002) menemukan fakta bahwa keterikatan kerja memberikan sumbangan efektif sebesar $\quad 16 \%$ terhadap profitabilitas, $18 \%$ pada produktifitas, $25 \%$ terhadap penurunan tingkat turnover yang tinggi, $49 \%$ terhadap penurunan tingkat turnover yang rendah, 37\% terhadap penurunan ketidakhadiran, dan $60 \%$ pada kualitas kerja. Tingginya keterikatan kerja sangat penting dalam meningkatkan performa dan produktivitas organisasi.

Bukti mengenai anteseden dan konsekuensi dari keterikatan kerja dapat diatur dalam keseluruhan model keterikatan kerja. Dalam membangun model ini, kita menggunakan dua asumsi dari model permintaan pekerjaan (JD-R) (Bakker dan Demerouti, 2007; Demerouti et al., 2001). Asumsi pertama adalah bahwa job resources seperti dukungan sosial dari rekan kerja dan supervisor, umpan balik kinerja, variasi keahlian, dan otonomi, memulai proses motivasi yang mengarah pada keterikatan kerja, dan akibatnya untuk kinerja yang lebih tinggi. Asumsi kedua adalah bahwa job resources menjadi lebih menonjol dan mendapatkan potensi motivasi mereka saat karyawan dihadapkan pada tuntutan pekerjaan yang tinggi (misalnya beban kerja, tuntutan emosional, dan tuntutan mental). Selanjutnya, kami menggunakan karya Xanthopoulou (2007), yang mengembangkan model JD-R dengan menunjukkan bahwa pekerjaan dan personal resources saling terkait, dan person resources dapat menjadi prediktor independen untuk keterikatan kerja.

Karyawan dapat dikatakan memiliki work engagement jika karyawan tersebut merasa penuh dengan energi dan memiliki ketahanan mental saat bekerja (Schaufeli \& Bakker, 2002). Bakker dan Demeuroti (2008) menyatakan bahwa ada dua faktor yang memengaruhi dapat keterikatan kerja yaitu sumber daya pekerjaan dan sumber daya pribadi. Sumber daya pekerjaan terdiri dari beberapa macam yaitu timbal balik kerja (Performance Feedback), dukungan rekan kerja (Social Support), Pelatihan pimpinan (Supervisor Coaching), kesesuaian pegawai dengan organisasi (person-organization fit), dll. Kemudian, sumber daya pribadi juga terdiri dari beberapa macam yaitu modal psikologis (psychological capital), Keberhargaan diri (self-esteem), keyakinan diri (self-efficacy), optimis (optimism), ketahanan (resilience), dll.

Berdasarkan pemaparan diatas, penelitian ini dilakukan untuk melihat apakah ada pengaruh dari pelatihan 
psychological capital untuk meningkatkan work engagement pada karyawan PT. Bhanda Ghara Reksa (Persero) Surabaya. Penelitian ini melibatkan beberapa divisi, yaitu keuangan, sekertaris, pemasaran, operasional dan SDM. Partisipan diberikan kuesioner The Utrecht Work Engagement yang dikembangkan oleh Bakker et al. (2003) sebelum dilakukan pelatihan, untuk melihat tingkat work engagement pada partisipan. Selang satu minggu setelah pengisian kuesioner awal, peneliti melakukan pelatihan psychological capital yang akan memasukan empat unsur psychological capital, yaitu hope, resilience, self efficacy dan optimism (Luthans, 2004). Setelah pelatihan diberikan kepada peserta, peneliti memberikan kuesioner The Utrecht Work Engagement untuk melihat apakah ada peningkatan work engagement setelah diberikannya pelatihan terkait dengan psychological capital.

Analisa dari penelitian ini menunjukan bahwa hipotesis penelitian ini dapat diterima. Selain itu, hasil dari uji hipotesis ini menunjukan adanya peningkatan work engagement yang dilihat dari mean penelitian, dari 67.75 menjadi 71.94. Sehinga dapat disimpulkan bahwa ada perbedaan yang signifikan antara work engagement sebelum diadakannya pelatihan dan setelah diadakannya pelatihan. Hal ini menunjukan bahwa pelatihan yang diberikan kepada peserta dapat meningkatkan work engagement secara signifikan.

Hasil penelitian ini didukung oleh penelitian terdahulu yang dilakukan oleh Rostianda dan Lihardja (2013) yang menyatakan bahwa adanya hubungan positif antara modal psikologis dengan keterikatan kerja. Disisi lain Prihatsanti dkk (2013) menunjukkan adanya indikasi hubungan positif antara modal psikologis dan keterikatan kerja, dimana modal psikologis menyumbang sebanyak $51,3 \%$ dari keterikatan kerja.

Modal psikologis adalah kondisi psikologi positif individu yang ditandai dengan keyakinan diri atau kepercayaan diri, optimisme, harapan (hope), dan ketahanan (Luthans, Youssef, dan Avolio, 2007). Jika individu memiliki modal psikologis yang tinggi ia dapat melakukan pekerjaannya dengan lebih baik. Individu dengan modal psikologis yang tinggi akan lebih terikat dengan pekerjaannya karena individu tersebut akan lebih yakin dan optimis dengan kemampuannya dalam menyelesaikan pekerjaannya. Menurut penelitian oleh Rostianda dan Lihardja (2013) yang menyatakan bahwa adanya hubungan positif antara modal psikologis dengan keterikatan kerja, hal ini tentu saja 
didukung dengan nilai pengaruh yang mencapai 37,9\%.

Berdasarkan pemaparan hasil dan tinjauan literature, dapat disimpulkan bahwa work engagement dapat ditingkatkan melalui peningkatan personal resource individu. Salah satu bagian dalam personal resource tersebut adalah psychological capital. Sehingga, dalam meningkatkan work engagement dapat dilakukan menggunakan pelatihan psychological capital.

\section{KESIMPULAN}

Penelitian ini dapat disimpulkan bahwa ada pengaruh psychological capital untuk meningkatkan work engagement pada karyawan di PT. Bhanda Ghara Reksa (Persero). Selain itu, pelatihan psychological capital yang telah dilakukan oleh peneliti terbukti dapat meningkatkan work engagement

\section{SARAN}

Bagi penelitian selanjutnya, terdapat beberapa saran yang dapat dilakukan, yaitu: Mengembangkan pelatihan dengan memperpanjang waktu pelatihan; Menghadirkan tokoh ahli untuk beberapa sesi pelatihan; Evaluasi work engagement juga dilakukan beberapa saat setelah pelatihan

\section{REFERENSI}

Bakker, A. B., \& Demerouti, E. (2008). Towards a model of work engagement. Career Development International, 13(3), 209-223.

Bakker, A. B., Schaufeli, W. B., Leiter, M. P., \& Taris, T. W. (2008). Work engagement : An emerging concept in occupational health psychology, 22(3), 187-200.

Bakker, A. B. (2011). An EvidenceBased Model of Work Engagement. Current Directions in Psychological Science, 20 (4), 265-269.

Larson, M. D., Norman, S. M., Hughes, L. W., \& Avey, J. B. (2013). Psychological capital : A new lens for understanding employee fit and attitutes, 8 .

Luthans, F., Luthans, K. W., \& Luthans, B. C. (2004). Positive psychological capital: Beyond human and social capital, 2004(February), 45-50.

Luthans, F., Avey, J. B., Avolio, B. J., Norman, S. M., \& Combs, G. M. (2006). Psychological capital development: Toward a microintervention. Journal of Organizational Behaviour

Myhre, M. (2014). The effects of personal resources on work engagement. 1-65. Schaufeli, WB \& Bakker, A. (2010). Work engagement: A handbook of essential theory and research. Work Engagement: A Handbook of Essential Theory and Research., 10-24.

Sweetman, D., \& Luthans, F. (2010). The Power of Positive Psychology: Psychological Capital and Work Engagement. In Bakker, \& M. Leiter, Work engagement : a handbook of essential theory and research (pp. $54-68)$. 
Xanthopoulou, D., Bakker, A. B., Demerouti, E., \& Schaufeli, W. B. (2007). The Role of Personal Resources in the Job DemandsResources Model, 14(2), 121 